International Journal of Child, Youth and Family Studies (2012) 1: 1-19

\title{
“HERE WE ARE, AMAZINGLY ALIVE": HOLDING OURSELVES TOGETHER WITH AN ETHIC OF SOCIAL JUSTICE IN COMMUNITY WORK
}

\section{Cathy Richardson and Vikki Reynolds}

\begin{abstract}
In this paper, the authors describe their orientation to social justice based community work. The tenets of this work include: an ethical orientation towards staying alive in the work, descriptions of social justice, engaging with a hopeful skepticism, responding to privatized pain with justice-doing, and contesting the individualism of "burnout". This is followed by reflections on the role of solidarity, the sacred, revolutionary love, resistance, and an ethic of belonging in the commitments to staying fully alive in community work. The authors discuss the importance of forging communities of care with other practitioners through shared and collectively held ethics.
\end{abstract}

Keywords: solidarity, sustainability, resisting burnout, social justice, belonging, ethics

Acknowledgements: As Bud Osborn says, "No human being accomplishes anything alone” (1999, p. v). We acknowledge the profound contributions of people we work alongside, who are amazingly alive, and who are struggling to stay alive amazingly. We are grateful to the anonymous reviewer who provided such an insightful and generative critique. We also thank Susan Illvitsky for her energy and assistance in structuring the paper, and Erica Jacquet for her assistance with editing and submission. Andrew Larcombe, Jennifer White, and CharlesWaldegrave offered insightful critique which improved and expanded the usefulness of this writing. Thanks to Ga Ching Kong and Jeff Smith for their accounts of belonging and for their spirited ongoing solidarity.

Cathy (Kianewesquao) Richardson, Ph.D. is a Metis family therapist, activist, researcher, and Associate Professor at the University of Victoria School of Social Work, 3800 Finnerty Road, Victoria, BC, Canada, V8E 2Y2. E-mail: cathyr@uvic.ca.

Vikki Reynolds, Ph.D., RCC is a consultant, supervisor, activist, and instructor with the Vancouver School of Narrative Therapy, Vancouver, BC, Canada. E-mail: vr@vikkireynolds.ca 
International Journal of Child, Youth and Family Studies (2012) 1: 1-19

"So here we are amazingly alive, against long odds and left for dead" (Bud Osborn, Vancouver Downtown Eastside Poet/Activist, 1999, p. 9)

Joe, a First Nations Elder with shaggy hair and an uncertain smile, shows up at my counselling office and I almost fall off my chair. Outreach workers have been looking for him because his health is so risky, he's homeless again, and he hasn't checked in with his parole officer. Everyone is concerned for his life. We are beginning to suspect that he is either dead or in jail.

I say, "Joe! How are you?"

He catches me up on the hell he has crawled through. I ask him to teach me how he "crawled through hell."

He says, "Julie, a worker at detox, kept me alive." Joe says he puked on her twice and she just kept cleaning him up. When he was thinking of leaving detox, she followed him to the door telling him she would miss him. He was "nicing out" and she found him a cigarette. He said he was rude to her and she refused to take it personally, and told him she knew he could be more respectful.

I said, "That is amazing, have you told her that? Let's call her!" We call detox and actually get Julie on the speakerphone.

I say, "Julie, Joe is here and he's just told me that you are a reason he is still alive."

Julie cuts me off excitedly, "Joe is alive?” She is amazed. alive."

I say, "Yeah, yeah, he is right here and he says that you are a reason he is

In a shaky voice, Joe says, "She remembers me?"

Julie responds, "Of course I remember you Joe, you puked on me twice!"

I ask Julie what it means to her that Joe is saying that she is a reason that he is alive.

She responds, "Man, I can go to work for five years on this!"

I ask Joe what it means to know that he is going to help Julie go to work for the next five years. In a dignified voice Joe says, "Maybe I'll help her keep a couple more guys alive." i

Staying amazingly alive in community work over the long haul requires a rich engagement with our collective ethics and spirited relations of solidarity. We will start with an orientation of accountability to the Indigenous people whose territories we stand on. We will describe our orientation to our social justice-based community work which includes: our ethical orientation towards staying alive in the work, descriptions of social justice, engaging with a hopeful skepticism, responding to privatized pain with justice-doing, and contesting the individualism of "burnout". We will reflect on the role of solidarity, the sacred, revolutionary love, resistance, and an ethic of belonging in our commitments to staying fully alive in our work. While we are writing collaboratively, at times we will speak as ourselves, Cathy or Vikki, in order to locate ourselves culturally and to resist conflating our important differences. We will use 
International Journal of Child, Youth and Family Studies (2012) 1: 1-19

a different font from our collaborative writing to indicate that we are speaking individually, and will begin these pieces with a name in parenthesis to identify which of us is speaking.

\section{Starting Where We Stand, on Joe's Land}

We stand on land soaked in the blood of an unreconciled genocide that occurred on unceded Indigenous land. Part of the history of colonization in Canada has been the euphemistically called residential schools. Former federal minister Duncan Campbell Scott articulated the mandate of these schools as trying "to kill the Indian in the Child" (Paul, 2006). "The residential schools were a key part of the broader and longer term colonial strategy that included genocide, land theft, and ethnocide. As far as Euro-Canadian treatment of Aboriginal peoples is concerned, colonialism is the plot that drives every chapter" (Coates \& Wade, 2009, p. 2). In June 2008 the Canadian Prime Minister offered an apology from the government for abuses at these "schools".

[Cathy] I watch my Prime Minister's official apology to Joe and his people for residential schools from a reserve with former residential school inmates. Everyone is crying. Some leave, it is too much to watch. As a Canadian with Metis, Cree, Gwichin, Dene, and European ancestry, I watch this federal performance beside people who are visibly tormented by memories of state-imposed violence against children.

[Vikki] My Prime Minister never asked me or other settler people if we were sorry, or what we were sorry for, if we wanted to be accountable or how we wanted to be accountable for this political violence. It is an empty apology, given on my behalf, that pretends to clean my slate, requiring me to acknowledge nothing and to do nothing.

In our partnership, no matter who we work with, we never forget where we are standing. We always start our work from this place, with our feet solidly positioned on the land on which we live, land that was never surrendered.

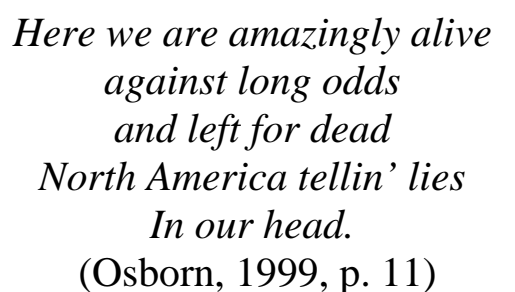

\section{Our Ethical Orientation towards Staying Alive in the Work}

As community workers committed to social justice, we are ethically obliged to find ways to be "amazingly alive" in our work. The sustainability that promotes being amazingly alive refers to a spirited presence and a genuine connectedness with others. It requires more than resisting "burnout" and keeping a desperate hold on hope. We are amazingly alive in our work when we are able to be fully and relationally engaged, stay connected with hope, and be of use to clients across time. Being amazingly alive in our work embraces a rich engagement with a spirit of social justice, and openness to the transformations we may experience as practitioners in this difficult work (Martín-Baró, 1994). 
We promote our sustainability through contesting injustice and committing to an ethic of doing justice (Reynolds, 2010a). If we are not working from this ethic, we risk replicating dominance and causing harm to our clients and community members. Staying alive in our work is not something we can do alone. It is relational and reflects a professional and ideological commitment to participating in collective action. Shouldering each other up in the work, in alignment with our shared ethics, fosters a solid(arity) ground on which we can join against the separation and privatization of personal pain. From here we may contest power structures that cause harm to people, while minimizing the harm to ourselves that is caused by structural isolation.

In these contexts of social injustice, in a society that is more just to some than to others, it is hard to stay alive in work alongside people who live in the margins and are forced to dance with death. This is where we work and our clients live. Despite this dismal reality, here we are, amazingly alive. Our ethical orientation is the medicine that keeps us alive and well. We strive to enact these ethics.

\section{Describing Social Justice}

[Cathy] What is social justice from an Indigenous or Metis perspective? (I use the term Indigenous to be inclusive, as Metis people are excluded by the term First Nations. Native is a kitchen table word my family has used to refer to themselves, and we think of Aboriginal as more of a government word.) An Indigenous world view encompasses shared values of how to live, be together, and take care of one another. Mohawk psychiatrist Clare Brant (1990) articulated certain "Native ethics" in an inspiring article, outlining an ethic of non-interference, non-competitiveness, sharing, and a Native sense of time and timing. What stands out particularly is the ethic of holding one's own counsel in terms of thought, opinion, or judgment about the actions of others. It is unethical to give advice or tell other people what to do.

Storytelling is a respectful teaching practice in Indigenous life and serves to put experience in context, to inform the imagination and ethics of children, to teach, to soothe. Stories provide moral explanations for human action. They educate young people. They explain creation and the reason for human existence. They may share information about the natural world and appropriate interaction between humans and other aspects of creation. Stories are shared orally; they are spoken or sung. Native Literature professor Thomas King (2003) writes that "Stories assert tremendous control over our lives, informing who we are and how we treat one another as friends, family and citizens" (p. 9). Stories form a theoretical prescription of how to behave within the parameters of the culture (Richardson, 2004) and are imbued with the great mystery, sacredness, and recipes for social justice.

In the Metis buffalo hunt, there was a code of ethics aimed to keep everyone safe and ensure that everyone had enough food. Violations of the communal code of ethics were punished with various forms of public humiliation. Dignity was something earned through bravery and honourable participation, and people were held accountable for transgressions in ways appropriate to the times, such as cutting up one's saddle for dishonourable conduct. Inclusion, belonging, and participation in community were the central organizing principles which advanced the prospects of social justice (Metis Family Services, n.d.).

When we refer to social justice from a Metis or Indigenous perspective we are describing a quality and a practice of sharing wealth and resources, taking care of the most infirm or vulnerable, making sure that everyone is fed, clothed, cared for in mind and body, and offered belonging. The story we are telling is that everyone matters and everyone belongs.

[Vikki] From a Western perspective, a socially just society may be described as one in which all groups of people, regardless of background, are included in the political, economic, and social decisions 
International Journal of Child, Youth and Family Studies (2012) 1: 1-19

of that society (Orlowski, 2009). Building a just society is a collective responsibility that requires front line workers to become activists for social change both in their work with clients and in their lives. Social justice includes all domains of social life, beyond the more narrow scope of human rights and justice systems, which primarily uphold laws. Indian author/activist Arundhati Roy $(2005,2009)$ speaks of attacks on social justice, and draws important distinctions between social justice and human rights:

Today, it is not merely justice itself, but the idea of justice that is under attack. The assault on vulnerable fragile sections of society is at once so complete, so cruel, and so clever - all encompassing and yet specifically targeted, blatantly brutal and yet unbelievably insidious - that it's sheer audacity has eroded our definition of justice. It has forced us to lower our sights, and curtail our expectations. Even among the wellintentioned, the expansive, magnificent concept of justice is gradually being substituted with the reduced, far more fragile discourse of "human rights". (2005, p. 331)

The role of community workers/activists is to contribute to the making of a space in which the person who is oppressed gets to have their voice heard and listened to. Social justice requires more than being heard by a practitioner; a person's words must matter, not be dismissed, and be met with an accountable response. Brazilian Popular Education theorist Paulo Freire $(1978,2001)$ names this authentic dialogue, which he describes as an act of revolutionary love. If we are replicating oppression we are not in dialogue with each other. Activist/scholar Anita Lacey eloquently calls these spaces of justice, which community workers contribute to, "the social divine" (2005a).

American anarchist scholar Noam Chomsky (2005) cautions all of us in our assumption that we know what social justice is, or that we have hit some kind of developmental stage in humanism and that we can decide what is just. What is most hopeful for us in Chomsky's caution is the idea that we need to create a future in which something we could not even articulate presently as justice could be possible. Moments of the social divine hold glimpses of these possible just futures. Wittgenstein (1953) says that the limits of our language are the limits of our world. We do not even know the words to describe what it is we are working towards, because we cannot yet articulate it, and have not yet acted to create our vision of social justice.

There is often pressure on us as community workers to influence people into acceptable social norms and structures that do not fit with a just society. We resist these expectations that can result in us replicating oppression, and we enact our visions and hopes for justice-doing. When we speak of our work in relation to issues of social justice, we are acknowledging that many of our clients are in struggles for their lives, that these are issues of life and death.

Engaging with an ethic of justice-doing in our community work helps us to resist professional "talk of things hidden inside of the heads of individuals" (Shotter \& Katz, 1998, pp. 88-89). The brain and body are a part of the holistic person's struggles - but we hold this idea alongside our knowing that a brain is contained within a particular body that is moving in the world and is subject to power. Oppression does not happen to people in their brain. It happens to people in the world. Certainly oppression in the physical/social world is inscripted onto the body, but we respond with justice-doing in the social world which is the site of intervention.

\section{Responding with Justice-doing}

The helping professions' connections to ideals of neutrality and objectivity can invite us to accommodate clients to private lives of hell, which is not in line with any worker's ethics (Cushman, 2006). Many progressive front line workers have spoken of the activist and feminist analysis of private pain/public issue. For example, working with women who have survived rape requires us to keep confidentiality of a particular woman's story, and to speak publicly contesting 
the rape culture we live in. When we speak of the individualization of injustice and the privatization of pain, we are connecting with these rich histories from both activist and practitioner traditions that invite us to respond with justice-doing. In community work, Kiwi Tamasese (2001) of the Just Therapy team from Aotearoa/New Zealand speaks of "private issues, public problems”. Imelda McCarthy (2001), from Ireland's Fifth Province team writes of how "public problems become private and privatized issues" in therapeutic practice. These multiple voices call for an ongoing move to action, to continue the practices of resisting neutrality, and to work for change in the social world where clients and practitioners live. McCarthy (2001) writes:

It is crucial that the private issues of clients need to be entered into the public arena if social change is to occur. This publication does not refer to the specific details of confidential material but of the themes and trends.... The private and the public cannot be separated when one works with the poor; otherwise we are in danger of creating yet another arena for their silencing and further oppression. (pp. 271-272)

We are accompanied by these practitioners, and the rich history of voices legitimizing our activism and contesting neutrality. We have never been neutral about sexual abuse. We have never been neutral about torture. Neutrality is itself a particular political position. We take on oppression and injustices on all fronts, at the intersections of our power and privileges, where we have power and where we're oppressed (Crenshaw, 1995; Robinson, 2005).

Justice-doing requires immediate responses. Our work is imperfect, but required, and we cannot say to clients, “Continue your suffering. We'll get to you later when we know exactly what to do". We acknowledge that our responses to oppressive situations will be imperfect. Popular education has taught us to act and then reflect, analyze, and recreate our responses (Freire, 1970). We cannot wait for better training, the arrival of the right teacher, or finding the right book. We take what we have learned from activist cultures, from progressive trainings, and from our families and cultures, and respond to need with action. While maintaining a critique of the idea of solidified theories, we hold close a teaching from Chomsky (2005):

Social action cannot await a firmly established theory of man [sic] and society, nor can the validity of the latter be determined by our hopes and moral judgments. The two - speculation and action - must progress as best they can, looking forward to the day when theoretical inquiry will provide a firm guide to the unending, often grim, but never hopeless struggle for freedom and social justice. (p. 116)

Justice-doing is inspired by workers refusing to be contented with social cruelty. However, our work is not innocent and neutral positions are inherently political.

\section{A Hopeful Skepticism}

We invite a healthy and hopeful skepticism about whether or not we are enacting our ethic of justice-doing in any moment-to-moment interaction. Hopeful skepticism is informed by Ricoeur and Kvale's hermeneutics of suspicion (Kvale, 1996; White, 1991), where we look to our practice to 
International Journal of Child, Youth and Family Studies (2012) 1: 1-19

see if we are in accord with our ethics. Activists ask, “Am I walking the talk?” Holding an antioppression framework is fabulous, but theorizing is limited (Tuhiwai Smith, 1999). Critical theory on its own cannot deliver a just society.

[Vikki] What matters is that we enact our ethics. For example, I make claims to being an ally and to acting accountably for my access to heterosexual privilege. Whether or not I actually perform as an ally is best judged by the person facing the oppression. If a person who identifies as queer says, "You helped make space for my voice to be heard, then you got out of the way, and I experienced that as accountable", then I know that I am in line with my ethics and hope for being an ally in that moment. ${ }^{\text {ii }}$

\section{Contesting “Burnout” and Cynicism: Bringing Hope}

We are critical of the individualization of "burnout" and the limits of "self-care" which lays the burden of an unjust society on the backs of individual workers. We embrace the ethical practice of collective care. Our community work is often a front line response to violence, abuses of power, and other acts of oppression:

I believe that the level of what is being called "burnout" says a lot more about our society collectively than it says about us as counsellors individually. The problem is not in our heads or in ourselves, but in the real world where there is a lack of justice. The people I work alongside do not burn me out and they do not hurt me: they transform me, challenge me and inspire me. We're not "burning out", we're resisting being blown up! What is threatening to blow me up is an inability to work in line with my ethics, and my frustrating failure to personally change social contexts of injustice that clients wrestle with and live in. (Reynolds, 2009, p. 6)

"Burnout" is an overused term, and we believe that the problems that threaten our sustainability and effectiveness in our work are better described as spiritual pain. By this we mean the harrowing discomfort we experience bodily and spiritually when our work and our own limitations require us to work in ways that transgress and violate the very ethics that drew us to community work. This spiritual pain can be responded to with relationships of solidarity that help us hold close and enact our collective ethics (Reynolds, 2008, 2010b).

Staying amazingly alive in our work requires that we work in the world we are in, with what is, and not what should be. Discerning skepticism from cynicism is important. Cynicism can paralyze us into believing not only that we can do nothing, but that nothing can be done. We believe that contesting cynicism is an ethical obligation for workers who align themselves with an ethic of social justice.

Healthy skepticism can help us engage with ethics by questioning our assumptions and generating our desire for something different. Skepticism also invites community workers to look for evidence of the doing of the ethical positioning we claim, and not to smooth over the discomfort we experience when we transgress our collective ethics. In this sense, skepticism is in relationship with hope, and onside with staying alive in our work. "Cynicism might be an appropriate reaction to injustice that cannot be changed. Hope is an appropriate response to a task that, while difficult, is imaginable” (Jensen, 2001, p. 2). Cynicism can be simple. Bringing a reasonable, believed-in hope to our work with clients is more complex and more difficult. 
International Journal of Child, Youth and Family Studies (2012) 1: 1-19

We believe in the correlation of hope and staying fully alive in our work. In this we are backed up by Freire (1970), who says, "Hopelessness is a form of silence, of denying the world and fleeing from it. The dehumanization resulting from an unjust order is not a cause for despair, but for hope, leading to the incessant pursuit of the humanity denied by injustice” (pp. 72-73).

\section{Honouring Resistance}

In saying we honour resistance, we are acknowledging that whenever people are oppressed they resist. Resistance is linked to repairing dignity when people's lives and identities are under attack. There are three main assumptions we make about resistance:

1. Whenever a person is oppressed they resist.

2. Resistance ought not to be judged by its ability to stop the oppression.

3. Resistance is important for its ability to maintain a person's connection to humanity, especially in instances outside of human understanding. (Wade, 1997; Reynolds, 2010c)

While resistance to oppression is ubiquitous, without a purposeful commitment to witness resistance, it can be disappeared, or be constructed narrowly, so that only that resistance which successfully stops oppression is acknowledged. Coates and Wade (2007) point out that language is used to either conceal or reveal violence and resistance. In clarifying real events in the world, we look for the person's own account of their sites of resistance, their resistance knowledges (Wade 1996, 1997), and the meanings these acts of resistance hold for the person.

Acts of resistance can draw attention to oppression that can go unnoticed and unchallenged or can pass for normal. In fact, acts of resistance can be indicators of safety and draw attention to the often ignored stories of the victims' efforts to protect themselves and others (Richardson \& Wade, 2008). Resistance may not stop violence or social cruelty, but it does connect us with our sense of humanity and collective dignity. However, we are careful to not fetishize resistance, and certainly, not every act is an act of resistance. Our hope is to transform our communities and society so that people can experience justice, not to witness acts of resistance for their own sake. When we (professionally, collectively) organize our community work around uplifting human dignity and contesting socio-political acts of oppression and cruelty, we demonstrate that our practice can offer social esteem and a kind of liberatory engagement, affirming life.

So most days now

I say shout

Shout for joy

Shout for love

Shout for you

Shout for us

Shout down this system

Puts our souls in prison.

(Osborne, 1999, p. 11) 


\section{Enacting Solidarity}

Solidarity speaks to the interconnections of our collective movements towards social justice, and in resisting oppression. Profoundly relational understandings of solidarity have been credited to different Indigenous Elders. Lily Walker, an Australian Aboriginal women's leader, describes solidarity beautifully while speaking to non-Aboriginal activists at a land rights protest: "If you come here to help me, then you are wasting your time. But if you come here because your liberation is bound up in mine, then let us begin" (Walker cited in Sinclair, n.d.).

[Vikki] I heard a retelling of this wisdom when I was involved in a protest against uranium mining in Kakadu, Australia. There were few non-Aboriginal folks present, and the Aboriginal Elder who was opening the event used a retelling of this phrase. Was I there for her, for me, or for us? I did not participate in this land rights protest for Aboriginal people, but rather because my life and my relational ethics are inextricably linked to solidarity with these struggles. I live on land that is unceded territory of other Indigenous nations: Different people, same issue. Other ethical commitments I hold for sustainable environmentalism and against war prompted me to take a position against the mining of uranium, a product directly connected to the weaponry of warfare and imperialism. The threads of these particular complexities woven together connect me and this Aboriginal Elder in solidarity.

There is always more solidarity than we can see. Unbeknownst to me, in protesting the mining of uranium, I was taking a position in solidarity alongside Cathy. When I met Cathy she had just had her third hip replacement and explained to me that this was a result of a birth defect related to her family's participation in uranium mining.

[Cathy] When my mother was a teenager, her family moved to Uranium City where her father took a job at a uranium company. Their family life consisted of seasonal work, trapping, hunting, and food gathering. During this time, workers and community members were not given accurate information about the dangers of uranium and radiation. Clearly, the government and the military were aware of its profound destructive capacity to cause harm as they were developing the atomic bomb. I have heard of an Indigenous prophecy that warned of the black rock in the ground and how it should not be removed by humans or their machines. By the time my grandmother Evelyn reached her middle adult years, she had lost all her hair. She had kept radioactive rocks as borders for her flower garden. My grandfather had kept uranium samples in the basement and my mother worked in a laboratory. My family suffers from many related health problems, including two generations of baby girls who could not walk without surgical or medical intervention. Uranium City is not too far from Deline, also known as the Village of Widows (Blow, 1999). After loading ore onto boats with bare hands, every single man in this village died. The uranium for the atomic bombs dropped on Japan came from Deline. There are now local Indigenous committees deciding how the mining industry should interact with the Dene community (M. Kodakin, personal communication, 2010).

Our solidarity can be imperfect and fluid; we're not invested in perfect relationships of unity or cohesion. We look for points of connection, and spaces where we can back each other up authentically. This is informed by activist understandings of "groundless solidarity", meaning that no site of oppression becomes the primary issue we organize around. We are inspired by Canadian anarchist theorist Richard Day's idea of "infinite responsibility” which invites us to always attempt to be "open to another other", to the multiplicity of ways that we might not be enacting our collective ethics and not in solidarity across our differences and privileges (Day, 2005, p. 18). Our impermanent allegiances are based on situational and timely concerns that bring people together for moments of sacred collision and cooperation.

Cathy engaged with the practices of solidarity in a unique way as she gave the opening lecture at a Minding the Gap conference in Victoria. She put three chairs on the stage behind the 
podium. She invited her colleague, Allan Wade, who is well published, holds a Ph.D., and is of Mennonite/German/Dutch and Scottish ancestry, to sit in the middle chair. On either side of him she placed a book written by other white men who are also well published and held Ph.D.s. Cathy made public to all of us that her purpose was to show that white people, with authenticated and privileged voices, were saying the same things that she was saying as a Métis person. Cathy let us know that she was doing this to remind herself that she knew the facts, and that they were correct. Allan's presence, sitting down behind her, reminded her that she was not crazy, and that there were nonAboriginal allies who would back her up when she named colonization. This particular and seemingly small act of solidarity shoulders us all up and fosters our hopes for respectful partnerships in our work and our lives across the differences of power that divide us.

\author{
And shout with my soul \\ Shout for life \\ More abundantly \\ Shout for all \\ Hard-pressed messed-with human beings
}

(Osborn, 1999, p. 10)

\title{
An Ethic of Belonging
}

For us, the necessity of belonging in community cannot be overstated, and we believe that a risk of not belonging is death. Our lives and work have taught us that hate is not a metaphor, and that hate kills. Hate works to divide people off from communities of inclusive liberatory belonging where culture can offer sites of healing (Reynolds, 2002).

In 2007 the American Journal of Public Health published research that revealed lesbian, gay, and bisexual youth are twice as likely to think about suicide as heterosexual youth, and three times as likely to attempt suicide (Silenzio, Pena, Duberstein, Cerel, \& Know, 2007). In 2010 the National Center for Transgender Equality released findings that $41 \%$ of the transgender persons they interviewed had attempted suicide. These stark numbers could not take into consideration the transgender people who had died of suicide. Reported numbers of suicides are always low because a death is only considered suicide when proven by legal investigations. Transgender and queer persons are not killing themselves on their own. We believe that hate, particularly racism, homophobia, and transphobia, have a hand in these killings. This is not a metaphor. Using the language of "suicide" and "overdose” masks the heart-wrenching suffering, daily indignities, and desolation many people experience. Queer, trans, and racialized persons are given many violent messages that they do not belong, and that there is no place for them on the planet. A medicalized term such as "overdose" quiets our collective discomfort, and provides a "cause" for these stolen lives. Concealing the violence of hate holds people criminally responsible for their own deaths, when they have been fighting hate to stay alive. "Suicide" blames the victims, and lets our society allow hate to continue unnamed and unchallenged in these deaths. Justice-doing requires we belong queer, trans, and racialized persons in our communities, and uphold our social responsibility to address the conditions that promote the horror of suicide.

Fostering belonging is at the heart of our efforts to become amazingly alive in our work, and to promote the possibilities of being amazingly alive in others. A community colleague, Ga Ching 
International Journal of Child, Youth and Family Studies (2012) 1: 1-19

Kong, who is a counsellor and acupuncturist of Chinese, Irish, and English descent, articulates beautifully her understandings of our ethic of belonging:

Collective agreements in groups can be complex, or they can be simplified to the words Vikki uses, "Everyone is welcome.” This is profound. It is saying everything that is required to be said, as an ethic. When I use these three words in my work with youth and children, our bodies and spirits relax. Rather than being in our heads with detailed rules, these words resonate within our bodies - everyone belongs, no matter what. Belonging is something we all know how to do, each cell self-organizes to an authentic peace in a space where everyone belongs. (G. Kong, personal communication, 2010)

Saying that everyone is welcome requires that we create spaces of inclusion and engage with the complexities of enacting respect. We structure safety in public and committed ways in collaboration with each other, and develop accountability practices that hold us to this ethic of belonging. We cannot work without these engaged practices that provide the scaffolding for an ethic of belonging.

\section{Belonging Jeff}

Jeff Smith is a music therapist involved in community activism and social justice oriented therapies whose ancestors are from Ireland, England, and Holland. Following what anarchist philosopher Gilles Deleuze calls “lines of flight” (Deleuze \& Guattari, 1987) from the spiritual pain associated with injustice and oppression, Jeff has taken risks to align himself with clients and with his ethics (Smith, 2010). He has been in some relatively dark places but he still has light in his eyes.

[Cathy] Through recent developments with the Islands of Safety violence cessation project (Richardson, 2009), Jeff and I are forming a musical conspiracy, which means "breathing together" in solidarity, bringing music to people who have suffered the harm of violence and whose spirits are on the mend. In this, I am inspired with new life and breath in the work. Like Jeff, we hunger for our work to embrace ethical commitments and collectivity, for a move from longing to belonging (Carriere \& Richardson, 2009).

Finding Jeff, we invited him to belong with us in a networked community (Lacey, 2005a) of practitioners organized around an ethic of social justice in a community of concern (Madigan \& Epston, 1995). But we were reflexively asking him to let us in, belong to us. Jeff has connected us with his community of helpers in resistance to work that replicates dominance.

\section{Jeff's Response to His Belonging}

In dark moments when I notice the massive chasm between my politics and the dominant conservative view that permeates our work, I lean heavily on my community of concern. This community serves as a gathering place for nomads like me when we flee from the colonial swagger of dominant institutions. Connecting with my people provides an opportunity to blow off steam, rest, revitalize, share ideas, acknowledge multiplicity, and celebrate difference. While Cathy and Vikki's mentorship, supervision, and encouragement to question and engage in multiple analyses of these kinds of events has informed my 
personal ethics and politics of practice, it is their ongoing friendship that I value most. To experience revolutionary love in this work is life affirming. Sharing food, music, stories, and communities has been a way of resisting the boundaries set up by the institutionalization of mentorship. More like a jam session than a teacher-student knowledge transfer, this kind of belonging is an improvisational practice that is always embodied and moving through the rhizome (Deleuze \& Guattari, 1987), a place where multiplicities flourish and connect with the unknown. (J. Smith, personal communication, 2010)

We always seek to be part of communities of concern, to be supported in doing justice, doing dignity, and being accountable to specific communities and to each other for our transgressions. Through belonging we invite spirited and generous invitations to collective accountability. We are looking for cover, to be blanketed by one another. This belonging is our antidote to being "blown up" by "burnout” and by individualism.

\title{
The Sacred
}

[Cathy] Much of our work in community begins with an acknowledgement of the sacred, the land, and the connections between all living things. Metis songwriter Dana Lynn Seaborn has shared a prayer song invoked to open various meetings, gatherings and ceremonies:

\author{
When will we learn to see the sacred? \\ When will we learn we're not alone? \\ When will we find a way to heal our mother earth? \\ Then we'll find the sacred is our home. \\ (Richardson \& Seaborn, 2002)
}

My colleagues and I also find strength in singing the Women's Warrior Song or the Strong Woman Song to activate courage, commitment and a spirit of justice and inclusion.

My family from Fort Chipewyan lives in a toxic sludge of emissions from the tar sands. Lake Athabasca is the basin where fish and wildlife live and feed. My family hunts and fishes there; some of them work in Fort McMurray for economic reasons. Others are fighting illness while some are standing up for animals and Earth. I see these brave citizens at the United Nations trying to raise awareness about this industrial nightmare, then returning home to a country recently awarded the "Colossal Fossil" award for ecological destruction by over 500 non-governmental organizations (DeMelle, 2009). Whatever our position, we cannot escape the outfall when we live in community together. So, under these conditions, how can we uphold the sacred in all levels of interaction, whether deep, mundane or in-between? These experiences of sacred unrest prompt me to keep aspiring for change.

When I return to northern Indigenous communities, I am embraced by a deep embodied sense of belonging, of being "home". I see people on the street that look like family. While I have never lived in the north, I feel the presence of my ancestors. Cheryl Aro, a Gitksan Woman from the Gutginuxw House and the Fireweed, sister and colleague of mine, refers to this as a "blood memory", and is a deep recognition of connection and belonging to people and places of Indigenous knowers ( $C$. Aro, personal communication, September 2010). The land welcomes me and I am belonged. It is this territory outside of language that moves me to be useful, to continue to walk and struggle alongside the Kaska, the Dene, the Gwichin - the people. It lives within us across lives and pulls us back to places where our ancestors have walked.

[Vikki] My understandings of the sacred are grounded in my Irish Catholic roots, my family, and my places of cultural belonging. I am moved by being in communion with others, responding to something made possible in the social divine, and being in webbed relationships of revolutionary love within a spirit of solidarity. My father, Bill Reynolds, taught us how to hold an extensive clan together with belonging and 
International Journal of Child, Youth and Family Studies (2012) 1: 1-19

compassionate love. My mother, Joan Reynolds, is the rock of our family, and taught us to be tenacious in holding onto love when it is hard.

My relationship with the sacred is not unlike a spirited solidarity that feeds me through my belonging in activist culture. As activists we create temporary communities as acts of resistance to the walls and fences put up around the sites of neo-liberal globalization such as the recent G-20 and G-8 events in Toronto. While activists are locked out, locked up, detained, and guarded by heavy security and military action, we create "spaces of inclusion" (Lacey, 2005b, p. 404) in direct response to our exclusion in these meetings of global power holders. "Activists create spaces of juxtaposition, in which diversity and inclusion are fostered... These spaces of justice are temporary expressions of what global anti-capital activists are striving towards...

expressions of the social divine, a sense of being together in self-directed and shaped environment" (p. 404). My experiences of participating in the spontaneous co-creation of these "deliberately forged spaces" (p. 407) accompanies me in our community work.

Embracing the sacred in our work alongside people who are suffering from mean-spirited policies and right-wing ideologies aligns us with Freire's ideas of revolutionary love. Freire (1970) describes revolutionary love as "emancipatory, and generative in terms of fostering further acts of love: It cannot co-exist with abuses of power” (p. 71).

Been o.d.'ed so bad made a doctor mad

Lookin' at me said

You're still alive

How can that be?

Said I don't know why I'm alive except I don't want to be

But I got news

For that doctor too

Right now I'm so alive

Feelin' so free

Doctor your science ain't nothing

Behind this

Mystery

(Osborn, 1999, p. 8)

\section{Amazingly Alive}

[Cathy] On the way back from a ceremony where I received my Cree spirit name, I was with some of my sisters at one of those gift shops at a ferry terminal. Someone had the idea that we all buy an animal pendant to mark our trip and ceremonial time together. I agreed, even though I wasn't particularly interested in the jewellery.

I wore the eagle pendant on a subsequent trip up north. There, in the Yukon, I attended a medicine wheel ceremony as a support person and ended up sitting with a young couple in a counselling session. At the end of our time together, the young Indigenous woman lingered and told me quietly that she thought my eagle pendant was pretty. I asked her if she would let me give it to her, as a memory of the place and the time together. She agreed and we placed the eagle around her neck. She started to gently cry. She said that this was the nicest thing that anyone had ever done for her. In fact, she said that no one had ever given her a present before. 
International Journal of Child, Youth and Family Studies (2012) 1: 1-19

There aren't words to describe a moment like that, the energy that moves between us and the great mystery, weaving us together in particular moments that remind us we are alive.

In this amazing valley, backed up by mountains, lakes, animals, and big sky, I imagined that she had been left for dead in those multiple foster homes and institutions that housed parts of her life. In that moment, something different happened that made the spirit dance.

\author{
shout here we are \\ amazingly alive \\ against long odds \\ left for dead \\ shoutin' this death culture \\ dancing this death culture \\ out of our heads \\ amazingly alive \\ (Osborn, 1999, p. 11)
}

This work is dedicated to Flora Tuhaka, often referred to lovingly as "Mother Truth" by her work colleagues, a Maori Elder with the Just Therapy team in Aotearoa/New Zealand, whose passion for sacred connectedness continues to move and inspire us. We miss her. 
International Journal of Child, Youth and Family Studies (2012) 1: 1-19

\section{References}

Alcoholics Anonymous. (2001). The big book (4th ed.). New York: Alcoholic Anonymous World Services.

Blow, P. (Director). (1999). Village of widows. [Motion picture]. Canada: Lindum Films Inc.

Brant, C. (1990). Native ethics and rules of behaviour. Canadian Journal of Psychiatry, 35(6), 534 539.

Carriere, J., \& Richardson, C. (2009). From longing to belonging: An Indigenous critique of applying attachment theory to work with Indigenous families. In S. McKay, D. Fuchs, \& I. Brown (Eds.), Passion for action in child and family services (pp. 49-68). Regina, SK: Canadian Plains Press.

Chomsky, N. (2005) Chomsky on anarchism (selected and edited by B. Pateman). Edinburgh: AK Press.

Coates, L., \& Wade, A. (2007). Language and violence: Analysis of four discursive operations. Journal of Family Violence, 22(7), 511-522.

Coates, L., \& Wade, A. (2009). "For this we are sorry”: A brief review of Canada's most recent non-apology to Aboriginal Peoples. In Under The Volcano festival of art and social change program. Vancouver, BC: Under The Volcano.

Crenshaw, K. (1995). Mapping the margins: Intersectionality, identity politics, and violence against women of colour. In K. Crenshaw, G. Gotanda, G. Peller, \& K. Thomas (Eds.), Critical race theory: The key writings that formed the movement (pp. 357-383). New York: The New Press.

Cushman, P. (2006, June). Where do psychotherapy narratives come from? Avoiding the arrogance of monoculturalism and the dead-end of relativism. Keynote address given at the Therapeutic Conversations 7 Conference, Vancouver, Canada.

Day, R. (2005). Gramsci is dead: Anarchist currents in the newest social movements. London: Pluto Press.

Deleuze, G., \& Guattari, F. (1987). A thousand plateaus: Capitalism and schizophrenia. London: Athlone Press.

DeMelle, B. (2009). Canada wins colossal fossil award. Retrieved August 2010, from http://tcktcktck.org/stories/campaign-stories/canada-wins-colossal-fossil-year-award

Fassinger, R., \& Arsenau, J. (2007). "I'd rather get wet than be under the umbrella”: Differentiating the experiences and identities of lesbian, gay, bisexual, and transgendered people. In K. Bieschke, R. Perez, \& K. Debord (Eds.), Handbook of counselling and psychology with lesbian, gay, bisexual and transgendered 
International Journal of Child, Youth and Family Studies (2012) 1: 1-19

clients (2nd ed., pp. 19-50). Washington, DC: American Psychological Association.

Freire, P. (1970). Pedagogy of the oppressed. New York: Continuum.

Freire, P. (1978). Pedagogy in process: The letters to Guinea Bissau. New York: Seabury Press.

Freire, P. (2001). Pedagogy of freedom: Ethics, democracy and civic courage. Lanham, MD: Rowman and Littlefield.

Jensen, R. (2001). Critical hope: Radical citizenship in reactionary times. Retrieved September 8, 2003, from http://www.commondreams.org/cgi-bin/print.cgi?file=/views01/1217-05.htm

King, T. (2003) The truth about stories: A native narrative. Toronto: House of Anasai Press.

Kvale, S. (1996). Inter-views: An introduction to qualitative research interviewing. London: Sage Publications.

Lacey, A. (2005a). Networked communities: Social centres and activist spaces in contemporary Britain. Space and Culture: The Journal, 8(3), 286-299.

Lacey, A. (2005b). Spaces of justice: The social divine of global anti-capital activists' sites of resistance. Canadian Review of Sociology / Revue canadienne de sociologie, 42(4), 403420.

Madigan, S., \& Epston, D. (1995). From “spy-chiatric gaze” to communities of concern: From professional monologue to dialogue. In S. Friedman (Ed.), The reflecting team in action: Collaborative practice in family therapy (pp. 257-276). New York: Guilford Press.

Martín-Baró, I. (1994). Writings for a liberation psychology. Cambridge, UK: Harvard University Press.

McCarthy, I. (2001). Fifth province re-versings: The social construction of women lone parents' inequality and poverty. Journal of Family Therapy, 23(3), 253-277.

Metis Family Services. (n.d.). Metis culture: The buffalo hunt. Retrieved September 6, 2010, from http://www.metisfamilyservices.com/metis-culture

Narcotics Anonymous. (1988). Narcotics Anonymous basic text (5th ed.). Van Nuys, CA: World Service Office.

Nataf, Z. (1996). Lesbians talk transgender. London: Scarlet Press.

National Center for Transgender Equality. (2010). Retreived October 1, 2010, from http://transequality.org/PDFs/NCTE_Suicide_Prevention.pdf

Orlowski, P. (2009). “That would certainly be spoiling them”: Liberal discourses of social studies teachers and concerns about Aboriginal students. Canadian Journal of Native Education, 31(2), 110-129. 
International Journal of Child, Youth and Family Studies (2012) 1: 1-19

Osborn, B. (1999). Hundred block rock. Vancouver, BC: Arsenal Pulp Press.

Paul, D. (2006). We were not the savages: Collision between European \& Native American civilizations (3rd ed.). Winnipeg, MB: Fernwood Press. Retrieved September 2010, from http://www.danielnpaul.com/IndianResidentialSchools.html

Reynolds, V. (2002). Weaving threads of belonging: Cultural witnessing groups. Journal of Child and Youth Care, 15(3), 89-105.

Reynolds, V. (2008). An ethic of resistance: Front line worker as activist. Women Making Waves, 19(1), 5.

Reynolds, V. (2009). Collective ethics as a path to resisting burnout. Insights: The Clinical Counsellor's Magazine \& News, December 2009, 6-7.

Reynolds, V. (2010a). Doing justice as a path to sustainability in community work. http://www.taosinstitute.net/Websites/taos/Images/PhDProgramsCompletedDissertations/Re ynoldsPhDDissertationFeb2210.pdf

Reynolds, V. (2010b). A supervision of solidarity. Canadian Journal of Counselling, 44(3), 246257.

Reynolds, V. (2010c). Doing justice: A witnessing stance in therapeutic work alongside survivors of torture and political violence. In J. Raskin, S. Bridges, \& R. Neimeyer (Eds.), Studies in meaning 4: Constructivist perspectives on theory, practice, and social justice (pp. 157184). New York: Pace University Press.

Reynolds, V. (2010d). Fluid and imperfect ally positioning: Some gifts of queer theory. Context Magazine, Association for Family and Systemic Therapy, UK, October 2010, 13-17.

Richardson, C. (2004). Becoming Metis: The relationship between the Metis sense of self and cultural stories. Unpublished dissertation, University of Victoria, Victoria, BC.

Richardson, C. (2009). Islands of safety and the social geography of human dignity: A child and mother safety planning initiative for cases of paternal violence in child welfare. Federation of Community Social Services of BC, Research to Practice Network.

Richardson, C., \& Seaborn, D. (2002). Working with Metis children and their families. The B.C. Counsellor, 24(2), 47-51.

Richardson, C., \& Wade, A. (2008). Taking resistance seriously: A response-based approach to social work in cases of violence against Indigenous women. In S. Strega \& J. Carriere (Eds.), Walking this path together: Anti-racist and anti-oppressive child welfare practice (Chapter 12). Winnipeg, MB: Fernwood.

Robinson, T. (2005). The convergence of race, ethnicity, and gender: Multiple identities in counseling (2nd ed.). Boston: Pearson Education. 
International Journal of Child, Youth and Family Studies (2012) 1: 1-19

Roy, A. (2005). Peace and the new corporate liberation theology. In A. Roy, An ordinary person's guide to empire (Chapter 14). New Delhi: Viking by Penguin Books.

Roy, A. (2009). The chequebook and the cruise missile. New York: Harper Collins.

Shotter, J., \& Katz, A. M. (1998) "Living moments” in dialogical exchanges. Human Systems, 9, 81-93.

Silenzio, V., Pena, J., Duberstein, P., Cerel, J., \& Know, L. (2007). Sexual orientation and risk factors for suicidal ideation and suicide attempts among adolescents and young adults. American Journal of Public Health, 97(11), 2017-2019.

Sinclair, R. (n. d.). Participatory action research. In Aboriginal and Indigenous Social Work. Retrieved November 21, 2008, from http://www.aboriginalsocialwork.ca/special_topics/par/index.htm.

Smith, J. (2010). Entering the Rhizome: A description of a music therapy street outreach program. The Drumbeat, 11(2), 10-12.

Tamasese, K. (2001). Talking about culture and gender. In C. White (Ed.), Working with the stories of women's lives (pp. 15-22). Adelaide, Australia: Dulwich Centre Publications.

Tuhiwai Smith, L. (1999). Decolonizing methodologies: Research and indigenous peoples. London: Zed Books Ltd.

Wade, A. (1996). Resistance knowledges: Therapy with aboriginal persons who have experienced violence. In P. H. Stephenson, S. J. Elliott, L. T. Foster, \& J. Harris (Eds.), A persistent spirit: Towards understanding aboriginal health in British Columbia. (Canadian Western Geographical Series 31, pp. 167-206). Victoria, BC: Western Geographical Press.

Wade, A. (1997). Small acts of living: Everyday resistance to violence and other forms of oppression. Journal of Contemporary Family Therapy, 19(l), 23-40.

White, E. (1991). Between suspicion and hope: Paul Ricoeur's vital hermeneutic. Journal of Literature and Theology, 5(3), 311-321.

Wittgenstein, I. (1953). Philosophical investigations. Oxford, UK: Blackwell. 
International Journal of Child, Youth and Family Studies (2012) 1: 1-19

\section{Endnotes}

' [Vikki] "Joe" is a pseudonym in this composite and fictionalized account informed by multiple experiences. Joe's story demonstrates an enlivening “giving it back” practice, which I was taught by members of Alcoholics Anonymous (2001) and Narcotics Anonymous (1988) fellowships. This practice honours the recursive engagement between practitioners and the people they work alongside. We can catch workers up on the moments of their work that might be unknown to them but hold great meanings for clients. As workers, we are open to being transformed in this work, just as Joe is honoured here for his meaningfulness in Julie's life as a worker.

ii [Vikki] "Queer” has been adopted by groups of people I work with as an umbrella term for some people who do not identify as strictly heterosexual. I use this term to speak of lesbian, gay, bisexual, two-spirit, and queer identified people, acknowledging that this is a problematic term for many reasons (Fassinger \& Arsenau, 2007). People I work alongside who identify as queer may be in any of these groups, but primarily identify outside of heterosexual normativity, which refers to discourses which promote heterosexuality as normal. People who identify as trans do not identify strictly with the gender they were assigned to at birth, and may or may not transition to a gender in which they feel more congruent, which could be something other than male or female. They may or may not transition physically or socially to their preferred gender identity (Nataf, 1996). All of these terms are problematic, contested, and evolving. I use these terms for clarity and because groups of folks I work alongside have settled on this imperfect phrasing for now (Reynolds, 2010d). 